\title{
Metabolomics-Microbiome Crosstalk in the Breast Cancer Microenvironment
}

\author{
Mysoon M. Al-Ansari ${ }^{1,2}$, Reem H. AlMalki ${ }^{1,2}$, Lina A. Dahabiyeh ${ }^{3}\left(\mathbb{D}\right.$ and Anas M. Abdel Rahman ${ }^{4,5, *(D)}$ \\ 1 Department of Botany and Microbiology, College of Science, King Saud University, \\ Riyadh 11451, Saudi Arabia; myalansari@ksu.edu.sa (M.M.A.-A.); 439203044@student.ksu.edu.sa (R.H.A.) \\ 2 Department of Molecular Oncology, Cancer Biology \& Experimental Therapeutics Section, King Faisal \\ Specialist Hospital and Research Centre (KFSHRC), Riyadh 11211, Saudi Arabia \\ 3 Department of Pharmaceutical Sciences, School of Pharmacy, The University of Jordan, Amman 11942, Jordan; \\ 1.dahabiyeh@ju.edu.jo \\ 4 Metabolomics Section, Department of Clinical Genomics, Center for Genomics Medicine, King Faisal \\ Specialist Hospital and Research Centre (KFSHRC), Zahrawi Street, Al Maather, Riyadh 11211, Saudi Arabia \\ 5 Department of Biochemistry and Molecular Medicine, College of Medicine, Al Faisal University, \\ Riyadh 11533, Saudi Arabia \\ * Correspondence: aabdelrahman46@KFSHRC.edu.sa
}

Citation: Al-Ansari, M.M.; AlMalki, R.H.; Dahabiyeh, L.A.; Abdel

Rahman, A.M

Metabolomics-Microbiome Crosstalk in the Breast Cancer

Microenvironment. Metabolites 2021, 11, 758. https://doi.org/10.3390/ metabo11110758

Academic Editor: Daniel Globisch

Received: 29 August 2021

Accepted: 29 October 2021

Published: 4 November 2021

Publisher's Note: MDPI stays neutral with regard to jurisdictional claims in published maps and institutional affiliations.

Copyright: (c) 2021 by the authors. Licensee MDPI, Basel, Switzerland. This article is an open access article distributed under the terms and conditions of the Creative Commons Attribution (CC BY) license (https:// creativecommons.org/licenses/by/ $4.0 /)$.
Abstract: Breast cancer, the most frequent cancer diagnosed among females, is associated with a high mortality rate worldwide. Alterations in the microbiota have been linked with breast cancer development, suggesting the possibility of discovering disease biomarkers. Metabolomics has emerged as an advanced promising analytical approach for profiling metabolic features associated with breast cancer subtypes, disease progression, and response to treatment. The microenvironment compromises non-cancerous cells such as fibroblasts and influences cancer progression with apparent phenotypes. This review discusses the role of metabolomics in studying metabolic dysregulation in breast cancer caused by the effect of the tumor microenvironment on multiple cells such as immune cells, fibroblasts, adipocytes, etc. Breast tumor cells have a unique metabolic profile through the elevation of glycolysis and the tricarboxylic acid cycle metabolism. This metabolic profile is highly sensitive to microbiota activity in the breast tissue microenvironment. Metabolomics shows great potential as a tool for monitoring metabolic dysregulation in tissue and associating the findings with microbiome expression.

Keywords: metabolomics; microbiome; microenvironment; breast cancer

\section{Introduction}

Breast cancer is a heterogeneous disease and one of the world's most prevalent malignancies. According to the World Health Organization (WHO), 2.3 million women were diagnosed with breast cancer in 2020, with 685,000 deaths globally (https:/ / www.who. int/news-room/fact-sheets / detail/breast-cancer, accessed on 15 September 2021). Lately, Breast cancer incidence has increased to $29.7 \%$ among Saudi women [1]. Several risk factors are associated with breast cancer; they are mainly classified as modifiable and nonmodifiable factors. Non-modifiable risk factors include age, menopause, family history, hormonal variations, and genetic susceptibility. Modifiable risk factors such as diet, lack of physical activity, obesity, alcohol consumption, and oral contraceptive can be changed if appropriate measures are taken [1-3]. Normally, patients develop breast-related signs such as lumps, size alteration, pains, and nipple fluid discharge [4]. Although women are at a higher risk of developing breast cancer than men, breast cancer may occur in males, who represent less than $1 \%$ of overall breast cancer cases [5]. Despite the low incidence of breast cancer in males, the mortality rate is considered high as the disease is often only discovered at the final stage. Compared to females, breast tumors in males are more often of the ductal carcinoma type and estrogen- and progesterone-receptor positive [6]. 
There are five main molecular subtypes of breast cancer that are associated with the expression of three receptors in tumor cells, namely estrogen (ER), progesterone (PR), and human epidermal growth factor receptor-2 (HER2); Luminal A cancers largely correspond to ER or PR positive, HER2 negative, and low histological grade/proliferation rate, while Luminal B tumors display relatively lower levels of ER or PR expression, and either exhibit HER2 amplification, high histological grade/high proliferation, or both. The HER2enriched group (ERBB2) consists of ER-negative tumors and expresses genes mapping to the HER2 amplicon. Additionally, triple-negative breast cancer phenotype (TNBC) is formed by basal-like cancers characterized by low or /lacking levels of expression of ER and ER-related genes (including PR) and the frequent absence of HER2 overexpression. Normal breast-like subtype tumors show remarkable similarities with normal breast and fibroadenomas samples at the messenger Ribonucleic Acid (mRNA) expression level. There are three histological grades: grade 1-well-differentiated; grade 2-moderately differentiated; and grade 3-poorly differentiated [7-9].

Tumor microenvironment cells (TME) play a crucial role in cancer development and progression [10]. The heterogeneity of the TME mainly consists of the extracellular matrix (ECM) and various types of tumor stromal cells, including immune and inflammatory cells, endothelial cells, adipocytes, bone marrow-derived cells, and fibroblasts [11]. Endothelial cells are critical to the development of tumor angiogenesis, which provides metastatic tumor cells entry to the circulatory system [12]. Fibroblast cells are considered one of the most abundant and significant types of cells in the TME. Normally, fibroblasts play a key role in wound healing, epithelial differentiation regulation, and inflammation [13,14]. However, they are present in either activate or inactivated forms inside tumors, commonly known as cancer-associated fibroblast (CAF) or/myofibroblasts [13]. In cancer, CAFs trigger invasion, progression, and metastasis [15].

Before, the breast was initially thought to be sterile. Nowadays, multiple studies confirm that resident microbes in the breast [16] can be considered one component of the TME [17]. Therefore, the TME may provide favorable conditions for these microbes to survive and evolve [16]. Therefore, microbiota play a critical role in immune system development by promoting inflammation or suppressing anti-tumor immunity (as reviewed extensively in $[18,19])$. Thus, the dysbiosis of microbiota can contribute to breast cancer progression and other health conditions. The crosstalk between other types of microenvironment components, especially fibroblasts and the microbiome, as well as the microbiome more generally, is understudied.

Recently, researchers has shown great interest in understanding and connecting the inflammation mechanism involved in breast cancer with the breast tissue microbiome [2,20,21]. Disturbance of the microbiome has been linked to chronic diseases and malignancies, including breast cancer. Microbial alterations observed in breast cancer highlight the possible role of microbiota in breast cancer development, prevention, and management [3]. Microbiome expression is associated with the excreted metabolome, which helps study the disease phenotypes and develop biomarkers for disease management. This review introduces updated literature on the connection between the TME and breast cancer development, and discusses the association between the tissue microbiome and metabolic changes in disease development.

\section{Microbiome: An Overview}

The human microbiome is defined as the full array of the diverse microorganisms (microbiota) that live on and in humans, as well as their genetic materials. It is considered one of the leading environmental factors in disease development [20,21], with Firmicutes, Bacteroidetes, Proteobacteria, and Actinobacteria the dominant species [20,21]. Human microbiota manifestation is influenced by multiple environmental and physiological changes, including age, sex, race, geography, diet [22,23], host genetics and lifestyle, drugs like antibiotics [24,25], and interaction with the immune system [26] and metabolic pathway [27]. Several studies have linked the human microbiome with important health and disease 
conditions [28]. For instance, the gut microbiome was not significantly altered in premenopausal breast cancer patients compared to control. However, exceeded number of Escherichia coli, Citrobacter koseri, Acinetobacter radioresistens, Enterococcus gallinarum, Shewanella putrefaciens, Erwinia amylovora, and Actinomyces spp. was significantly reported in the postmenopausal group. However, the abundance of HPA0247, Salmonella enterica, Fusobacterium nucleatum, Eubacterium eligens, and Roseburia inulinivorans was lower in postmenopausal groups [29] (as reviewed extensively in [30-33]). A urinary-based microbiome study conducted in female breast cancer patients showed a high number of Corynebacterium, Staphylococcus, Actinomyces, and Propionibacteriaceae, and diminished number of Lactobacillus [34]. A previous study on the human oral microbiome using 16S rRNA Pyrosequencing and microarray reported abundant Firmicutes, Proteobacteria, Bacteroidetes, Actinobacteria, and Fusobacteria phyla. In addition, Streptococcus, Veillonella, Leptotrichia, Prevotella, and Haemophilus were common genera [35]. Herein, this review focuses on the breast tissue microbiome associated with breast cancer progression [32].

\section{Methods for Studying the Microbiota}

The microbiota can be studied directly using traditional culture-dependent or molecular approaches and indirectly through its association with other biomolecules or omics approaches such as epigenetics and metabolomics. The primary molecular technique for studying microbiota expression is DNA amplification of hypervariable regions using polymerase chain reaction (PCR). Microbiota identification (sequencing) and expression level are obtained using next-generation sequencing technologies (NGS) and microarray [35]. Multiple studies have explored the variable regions (V1-V9) 16S rRNA, shared by bacteria and archaea, using the NGS, whole-genome shotgun sequencing (WGS), and DNA microarray (e.g., PathoChip) techniques [36-38]. These techniques together have contributed to the study of the human microbiome and established an association between imbalance in the microbiome (dysbiosis) and disease phenotypes [39-42]. The International Human Microbiome Standard (www.microbiome-standards.org, accessed on 25 August 2021) and the Microbiome Quality Control project (www.mbqc.org, accessed on 25 August 2021), have developed standard operating procedures (SOP) designed to improve data quality and comparability in the human microbiome field (Figure 1) [38]. 


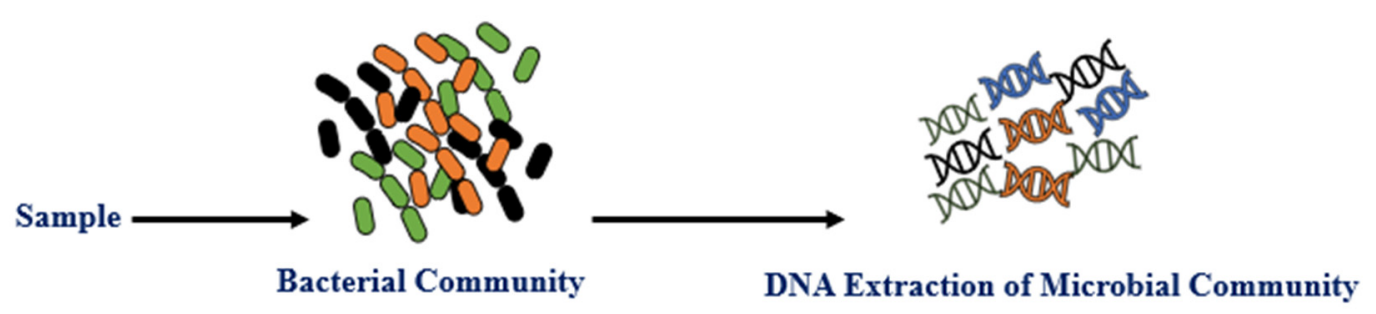

(a) 16S rRNA gene

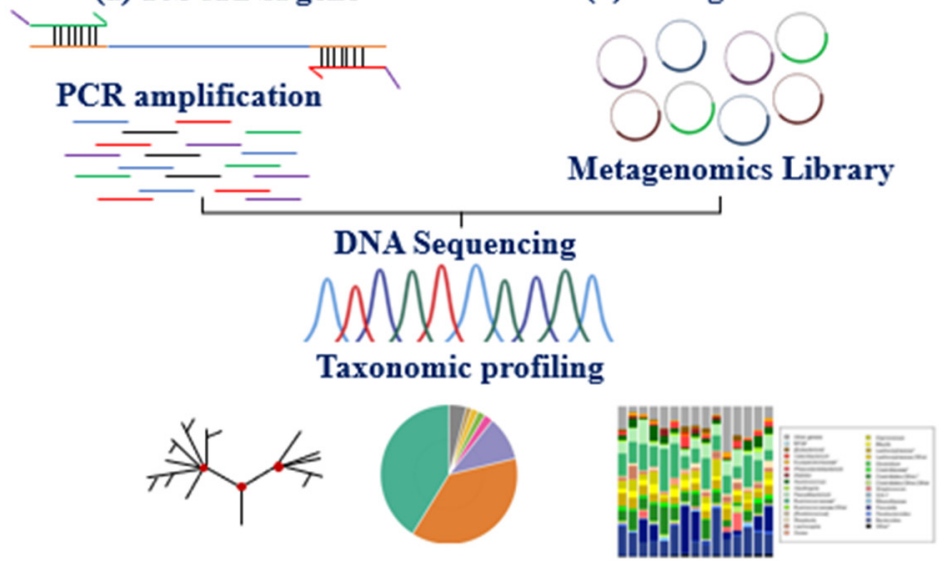

(c) Microbiome Microarray

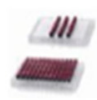

Axiom Microbiome Array

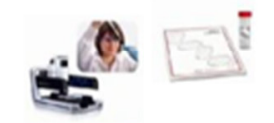

Target Preparation

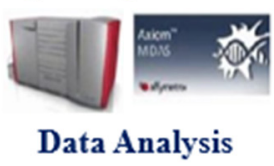

Figure 1. Workflow of common methods for studying the breast tissue microbiome. After extracting microbial DNA from breast tissue or cell lines. (a) a PCR amplification based on the 16S rRNA gene of variable regions (V1-V9) is conducted using specific primers to bacterial sequence species, where 16S rRNA is a shared region between bacteria and archaea. (b) Metagenomics is based on whole DNA sequencing generated from the sample, and the reads are matched with the library specific to the particular species. 16S rRNA gene provides phylogeny and community composition. Metagenomics also provides the community composition and function of genes. (c) Microbiome Microarray is designed using the high-density Axiom platform for microbiome analysis, containing 1.38 million DNA probes specific to microbiota species.

\section{Breast Tissue Microbiome}

The microbiota's dysbiosis has contributed significantly to breast cancer progression, and other health conditions, as reviewed elsewhere [21,24]. Microbes may, directly or indirectly, influence the development of breast cancer. The direct effect involves microbes on skin/breast tissue that contribute to breast cancer progression via contact with breast tissue. On the other hand, the indirect effect involves structural and functional components of bacteria, secretion products (e.g., quorum sensing peptides), or bacterial metabolites $[21,24,34,43]$. Several studies that describe the correlation between tissue microbiome dysbiosis and breast cancer development have revealed distinct species expression in patients compared to healthy individuals (Table 1) [44,45]. Urbaniak et al. [20] reported a higher abundance of Prevotella, Lactococcus, Streptococcus, Corynebacterium, and Micrococcus in healthy women, while Bacillus, Staphylococcus, Enterobacteriaceae, Comamondaceae, and Bacteroidetes were more abundant in women with breast cancer. In a more comprehensive study based on tissue samples collected from The Cancer Genome Atlas (TCGA), Mycobacterium fortuitum, and Mycobacterium phlei were found abundant in breast cancer tissues $(n=668)$ compared to the normal adjacent tissues $(n=72)$ [46]. Another study offered substantial evidence connecting breast cancer development to microbiome diversity and expression, where Methylobacterium growth was significantly decreased in cancer patient breast tissues [34]. A previous study reported a relative increase of Methylobacterium radiotolerans in tumor tissue versus Sphingomonas yanoikuyae in healthy adjacent tissue. The bacterial DNA

load showed an inverse correlation with the stage of breast cancer disease [2,47]. Therefore, bacterial load may be linked to reduced gene expression of the antibacterial response gene 
in advanced-stage breast cancer [2]. Costantini et al. [45] studied the multi-hypervariable region of the 16S-rRNA gene and found that the V3 region is the most informative for breast tissue microbiota. The microbiota imbalance may lead to downstream malfunction of the immune system, permitting tumor development [19]. Of note, most of these studies have sequenced the 16S rRNA gene using qPCR, NGS, or DNA microarray (PathoChip) methods for bacterial identification, as summarized in Table 1.

Table 1. Summary of studies investigating the alteration of breast tissue microbiome in breast cancer.

\begin{tabular}{|c|c|c|c|c|c|c|c|c|c|}
\hline \multicolumn{4}{|c|}{ Sample Type and Size } & \multirow[b]{2}{*}{ Method } & \multirow{2}{*}{$\begin{array}{l}\text { Variable } \\
\text { Region }\end{array}$} & \multicolumn{3}{|c|}{ Changes to the Microbiome } & \multirow[b]{2}{*}{ Ref. } \\
\hline Healthy & Benign & Cancer & Adjacent & & & $\begin{array}{l}\text { Healthy } \\
\text { Patients }\end{array}$ & Cancer Patients & Adjacent & \\
\hline & & 20 & 20 & NGS & $\mathrm{V} 4$ & & $\uparrow$ Methylobacterium radiotolerans & $\begin{array}{l}\uparrow \text { Sphin- } \\
\text { gomonas } \\
\text { yanoikuyae }\end{array}$ & {$[2]$} \\
\hline 24 & & 17 & 22 & NGS & V3-V4 & & $\downarrow$ Methylobacterium & & {$[34]$} \\
\hline \multirow[t]{2}{*}{23} & 13 & 45 & & NGS & V6 & $\begin{array}{l}\uparrow \text { Prevotella, } \\
\text { Lactococcus, } \\
\text { Streptococcus, } \\
\text { Corynebac- } \\
\text { terium, and } \\
\text { Micrococcus }\end{array}$ & $\begin{array}{l}\uparrow \text { Bacillus, Staphylococcus, } \\
\text { Enterobacteriaceae, Comamondaceae, and } \\
\text { Bacteroidetes. }\end{array}$ & & {$[20]$} \\
\hline & & 668 & 72 & NGS & V3-V5 & & $\begin{array}{l}\uparrow M y c o b a c t e r i u m \text { fortuitum and } \\
\text { Mycobacterium phlei }\end{array}$ & & {$[46]$} \\
\hline $\begin{array}{l}5, \\
\text { Cana- } \\
\text { dians }\end{array}$ & 11 & 27 & & NGS & V6 & & $\begin{array}{l}\text { The most abundant taxa in the } \\
\text { Canadian samples were: Bacillus } \\
(11.4 \%) \text {, Acinetobacter }(10.0 \%) \text {, } \\
\text { Enterobacteriaceae }(8.3 \%), \text { Pseudomonas } \\
(6.5 \%) \text {, Staphylococcus }(6.5 \%) \text {, } \\
\text { Propionibacterium }(5.8 \%), \\
\text { Comamonadaceae }(5.7 \%), \\
\text { Gammaproteobacteria }(5.0 \%) \text {, and } \\
\text { Prevotella }(5.0 \%) \text {. }\end{array}$ & & {$[48]$} \\
\hline 5, Irish & & 33 & & & & & $\begin{array}{l}\text { The most abundant taxa in the Irish } \\
\text { samples were: Enterobacteriaceae } \\
(30.8 \%) \text {, Staphylococcus }(12.7 \%), \text { Listeria } \\
\text { welshimeri }(12.1 \%) \text {, Propionibacterium } \\
(10.1 \%) \text {, and Pseudomonas }(5.3 \%) \text {. } \\
\uparrow \text { Escherichia coli }\end{array}$ & & {$[48]$} \\
\hline \multirow[t]{2}{*}{20} & & $\begin{array}{l}\text { 50, } \\
\text { BRER } \\
34, \\
\text { BRHR } \\
24, \\
\text { BRTP } \\
40, \\
\text { BRTN }\end{array}$ & & $\begin{array}{l}\text { PathChip } \\
\text { array }\end{array}$ & & & $\begin{array}{l}\text { Unique and common microbial } \\
\text { signatures in the major breast cancer } \\
\text { types are summarized in Table } 1 \text { in (51) } \\
\text { All four breast cancer types had } \\
\text { dominant signatures for Proteobacteria } \\
\text { followed by Firmicutes. } \\
\text { Actinomyces signatures were also } \\
\text { detected in each breast cancer types. }\end{array}$ & & {$[49]$} \\
\hline & & $\begin{array}{l}\text { 9, CNB } \\
\text { 7, SEB } \\
\text { 3, Both }\end{array}$ & $\begin{array}{l}\text { 9, CNB } \\
\text { 7, SEB } \\
\text { 3, Both }\end{array}$ & NGS & $\begin{array}{l}\text { V2-V4 } \\
\text { V6-V9 }\end{array}$ & & $\begin{array}{l}\text { Proteobacteria are the most abundant } \\
\text { phylum followed by Firmicutes, } \\
\text { Actinobacteria, and Bacteroidetes. } \\
\text { The presence of the genus Ralstonia is } \\
\text { associated with breast tissue. } \\
\text { The relative abundance of } \\
\text { Methylobacterium was different in } \\
\text { certain patients. }\end{array}$ & & {$[45]$} \\
\hline
\end{tabular}

NGS: Next-generation sequencing, qPCR: quantitative Polymerase chain reaction, BRER: endocrine receptor (estrogen or progesterone receptor) positive, BRHR: human epidermal growth factor receptor 2 (HER2) positive, BRTP: triple positive (estrogen, progesterone, and HER2 receptor-positive), BRTN: triple-negative (absence of estrogen, progesterone, and HER2 receptors), CNBs: core needle biopsies, SEBs: surgical excision biopsies. Up and down arrows refer to up- and down-regulated bacteria, respectively. 


\section{Metabolomics for Studying Breast Cancer}

Metabolomics is the global identification and quantification of a set of small molecules such as carbohydrates, nucleic acids, amino acids, and lipids within a biological system. A promising emerging analytical approach assesses the global metabolic expression associated with a certain health condition. Several biological materials might be used in this approach, including tissue samples. Metabolomics relies on the use of advanced analytical instruments with bioinformatics. Depending on the analytical platform, metabolomics might be studied in a targeted or untargeted fashion using nuclear magnetic resonance (NMR) or mass spectrometry (MS) [50]. Typically, MS is coupled with separation techniques such as liquid and gas chromatography (LC and GC, respectively) to improve metabolome coverage [51]. The latter is affected by study confounders (e.g., age, gender, ethnicity, diet, disease state, and drug exposure) that need to be addressed before exploring the diseaseassociated metabolic panel [52-54]. Over the years, metabolomics studies have received increasing interest as a promising advanced analytical approach for biomarker discovery, disease mechanism exploration, and therapeutic target identification [55]. In terms of cancer, metabolomics has demonstrated exceptional potential to provide a perspective on interactions between the tumor, host, and environment and within the cancer itself [56]. Metabolomics has provided new insights into different biological and clinical aspects of tumors, including profiling metabolic abnormalities associated with specific cancer types and monitoring cancer progression and therapeutic liabilities [57]. In breast cancer, most metabolomics studies use tumor tissues or cell lines with the goals of providing distinctive profiles for each subtype, distinguishing cancer or cancer with metastasis from normal tissues, predicting biomarkers for disease pathophysiology, monitoring treatment, and identifying new therapeutic targets [58].

The TME highly affects the metabolism of cancer cells. Breast cancer cells show characteristic pathological metabolic changes due to a complex rearrangement of the cellular energy signaling pathways. The metabolic pathways highly affected in cancer are glycolysis and mitochondrial oxidation (tricarboxylic acid cycle, TCA cycle) [33]. Disturbances to amino acid metabolism (mainly glutamine metabolism), nucleotide and lipid and fatty acid pathways, and protein translation have also been reported [52,59-62]. Changes in metabolism have a significant role in supporting the proliferation and angiogenesis of breast cancer cells. Aerobic glycolysis, or the Warburg effect, is a hallmark phenomenon in cancer. Most of the energy production comes through glycolysis, as opposed to mitochondrial oxidative phosphorylation in normal differentiating cells, in order to support the high proliferative activity of cancer cells [63]. A study by Martinez-Outschoorn et al. [64] on human cell lines demonstrated that loss of function in BRCA1 mutation led to the production of hydrogen peroxide and oxidative stress in epithelial breast cancer cells and in the stromal fibroblast microenvironment, and resulted in an increased expression of monocarboxylate transporter 4 (MCT4) to shuttle L-lactate out of cells. This finding highlighted the potential role of antioxidant therapies in breast cancer prevention. Moreover, the same study reported a loss of caveolin-1 (a marker for breast cancer progression) in CAFs, attributed to mutations of BRCA1 as a result of high glycolysis in stromal cells [64]. Lactate dehydrogenase (LDH) is one of the main TME metabolic enzymes, and is essential for converting pyruvate to lactate during glycolysis. Four LDH genes are known in the vertebrates, i.e., $\mathrm{LDHA}, \mathrm{LDHB}, \mathrm{LDHC}$, and LDHD, which are critically involved in cancer metabolism [65]. LDHA and LDHB, contribute to tumor stroma metabolic interaction and metabolic fuel exchange, and hence could serve as anticancer therapeutic targets. In particular, LDHB expression may serve as a predictive metabolic marker for therapeutic response in various cancers. In breast cancers, the expression of the LDHB gene (encodes LDH-1) has been used to evaluate response to neoadjuvant chemotherapy [66]. A previous study conducted on patients with basal-like cancers reported high expression levels of LDHB [67].

On the other hand, loss of LDHB expression in breast cancer (adenocarcinoma) tissues and cell lines due to promoter hypermethylation has been linked to metastatic develop- 
ment [68]. Various studies have shown that fibroblasts play a crucial role in developing tumor cells in the TME. Glycolytic tumor cells can generate lactate by converting glucose to pyruvate and generating the NAD+ needed for continuing glycolysis, an alternative route to the oxidative phosphorylation that occurs in normal cells. The increased concentration of lactate in the TME triggers MCT1, LDHB expression in the nearby stromal cells such as hMSCs/CAFs [69].

Metabolomics represents a promising advanced analytical approach for investigating the metabolome of breast cancer tissue. Metabolomics has identified specific metabolic alterations between four intrinsic subtypes of breast cancer (luminal A and B, HER2-enriched (ER-, HER2+), and TNBC) [33], and between ER+ and ER - breast cancer tissue metabolomes [55]. Moreover, using multiple tracer stable isotope resolved metabolomics, Lane et al. [70] have investigated the functional differences between different breast cell types (one primary breast and three breast cancer cells) and mouse tumor xenografts. They found that pyruvate carboxylation was activated in breast cancer versus primary cells and reported significant differences in glucose metabolism between in vivo and in vitro conditions emphasizing the influence of 3D cell architecture and/or tumor microenvironment [70]. Additionally, metabolomic studies have successfully enabled the identification of potential biomarkers for discriminating between breast cancer and normal tissues [60,62,71-73].

Breast cancer preferentially grows in adipocyte-enriched environments, which can induce changes in the composition of cells surrounding the tumor microenvironment affecting tumor cell proliferation [74]. Several lipidomics studies have highlighted lipid metabolism in breast cancer tissues compared to normal breast tissue [75-78]. A summary of the findings of the above metabolomics and lipidomics studies is presented in Table 2.

Table 2. Metabolomics in Breast Cancer. This is a summary of multiple studies used metabolomics to study breast cancer in different biological matrices $(\sqrt{ })$.

\begin{tabular}{|c|c|c|c|c|}
\hline \multicolumn{2}{|c|}{ Biological Materials } & \multirow{2}{*}{$\begin{array}{l}\text { Approach } \\
\text { (Targeted/Untargeted) }\end{array}$} & \multirow{2}{*}{ Altered Metabolites and Metabolic Pathways } & \multirow{2}{*}{ Ref. } \\
\hline Cell Line & Tissue & & & \\
\hline & $\sqrt{ }$ & GC-TOFMS (Targeted) & $\begin{array}{l}\text { Increased beta-alanine, 2-hydroyglutarate, glutamate, xanthine, and } \\
\text { decreased glutamine in ER- subtype compared to ER+ } \\
\text { Beta-alanine has shown the most significant change between breast } \\
\text { cancer ER- and ER+ }\end{array}$ & [55] \\
\hline & $\sqrt{ }$ & $\begin{array}{l}\text { LC-/MRM-MS } \\
\text { GC-MS } \\
\text { (Targeted and } \\
\text { Untargeted) }\end{array}$ & $\begin{array}{l}\text { Up-regulation of histidine, glutamine, tyrosine, creatine, } \\
\text { phenylalanine, lactic acid, adonitol, glutamic acid, and } \\
\text { downregulation of 3,7-cholest-5-ene. The study identified } \\
\text { tryptophan, tyrosine, and creatine, in serum and tissue as potential } \\
\text { markers for invasive ductal carcinoma (IDC). }\end{array}$ & {$[60]$} \\
\hline & $\sqrt{ }$ & GC-MS & $\begin{array}{l}\text { cytidine-5-monophosphate/pentadecanoic acid metabolic ratio was } \\
\text { a significant discriminator between cancer and normal tissues }\end{array}$ & {$[62]$} \\
\hline$\sqrt{ }$ & & $\begin{array}{l}\text { NMR } \\
\text { FT-ICR-MS }\end{array}$ & $\begin{array}{l}\text { glutaminolysis is connected to pyrimidine ring synthesis in all cell } \\
\text { types } \\
\text { anaplerotic pyruvate carboxylation was activated in breast cancer } \\
\text { versus primary cells }\end{array}$ & {$[70]$} \\
\hline$\sqrt{ }$ & & LC-MS/MS (Targeted) & $\begin{array}{l}\text { Glycine biosynthetic pathway was highly correlated with fast } \\
\text { proliferating breast cancer cells }\end{array}$ & [71] \\
\hline \multirow[t]{3}{*}{$\sqrt{ }$} & $\sqrt{ }$ & $\begin{array}{l}\text { LC-MS, GC-MS } \\
\text { (Targeted) }\end{array}$ & $\begin{array}{l}\text { Higher level of aspartate in breast cancer tissues than adjacent } \\
\text { non-tumor tissues, MCF-7 cell line than in MCF-10A cells }\end{array}$ & [72] \\
\hline & $\sqrt{ }$ & $\begin{array}{l}\text { MALDI MSI } \\
\text { (Targeted) }\end{array}$ & $\begin{array}{l}\text { Adenosine diphosphate, adenosine monophosphate, adenosine } \\
\text { triphosphate, aspartate, citrate, deoxycytidine diphosphate, fructose } \\
\text { 1,6-bisphosphate, glutamate, glutathione, glutathione disulfide, } \\
\text { guanosine diphosphate, N-acetylaspartate, NADH, UDP-glucose, } \\
\text { DP-N-acetylglucosamine, UDP, UMP }\end{array}$ & [73] \\
\hline & $\sqrt{ }$ & $\begin{array}{l}\text { GC-TOF-MS } \\
\text { (UPLC-MS) }\end{array}$ & $\begin{array}{l}\text { Phospholipids, including PtdCho-s, phosphatidylethanolamines, } \\
\text { phosphatidylinositol, sphingomyelin, triglycerides }\end{array}$ & {$[75,76]$} \\
\hline
\end{tabular}


Table 2. Cont.

\begin{tabular}{|c|c|c|c|c|}
\hline \multicolumn{2}{|c|}{ Biological Materials } & \multirow{2}{*}{$\begin{array}{l}\text { Approach } \\
\text { (Targeted/Untargeted) }\end{array}$} & \multirow{2}{*}{ Altered Metabolites and Metabolic Pathways } & \multirow{2}{*}{ Ref. } \\
\hline Cell Line & Tissue & & & \\
\hline & $\sqrt{ }$ & $\begin{array}{l}\text { LC-ESI-MS/NMR } \\
\text { (Targeted) }\end{array}$ & Up-regulation of choline, phosphocholine, glycerophosphocholine & {$[77]$} \\
\hline & $\sqrt{ }$ & $\begin{array}{l}\text { HR MAS MRS } \\
\text { (Untargeted) }\end{array}$ & $\begin{array}{l}\text { Up-regulation of phosphocholine, glycine, taurine, creatine, lactate, } \\
\text { ascorbate, and downregulation of glucose }\end{array}$ & [78] \\
\hline
\end{tabular}

\section{Interaction between Microbiome and Metabolomics in Breast Cancer}

Recently, interest in studying the association between the microbiome and metabolic alteration in cancer has increased. Microbiome metabolites can be critical modulators of the TME by regulating, either positively or negatively, vital processes such as inflammation, proliferation, and cell death [79]. However, research investigating the interaction between the microbiome and the metabolome in breast cancer is limited. Only a few reports have highlighted the association between the breast microbiome and metabolome in the breast cancer microenvironment. A previous study reported a higher abundance of Bacillus cereus in breast cancer patients compared with healthy controls. Bacillus cereus metabolizes progesterone into 5-alpha-pregnane-3,20-dione, stimulating cell proliferation and tumor progression $[20,80]$. Moreover, dysbiosis of the gut microbiome leads to elevated activities of $\beta$-glucuronidase, which is responsible for estrogen reactivation through the deconjugation of conjugated estrogens, and hence, an increased risk of estrogen-related conditions such as breast cancer $[81,82]$. A recent LC-MS metabolomics study reported a correlation between the gut microbiome and choline metabolism in breast cancer patients. The lower abundance of Faecalibacterium was linked to the upregulation of phosphocholine levels. [83]. The study suggested that combining flora-metabolites with the flora-bacteria (e.g., Faecalibacterium combined with phosphocholine) might serve as promising diagnostic biomarkers for breast cancer, and that Faecalibacterium may suppress breast cancer proliferation and invasion by inhibiting IL-6 signal transducers and activators of the transcription 3 (STAT3) pathway [83]. Lithocholic acid is a bacterial metabolite that could influence cancer cell proliferation through activation of the Takeda G-protein-coupled receptor 5 (TGR5) [84]. Bacterial metabolites, lithocholic acid, short-chain fatty acids, indole-propionic acid (IPA), or cadaverine can limit the proliferation of breast cancer cells [84-86]. These findings suggest that a deeper understanding of the link between microbiome and metabolome in breast cancer may provide new biomarkers as well as, therapeutic and prevention strategies.

\section{Conclusions}

Disturbances in the microbiota contribute to several pathological conditions, including breast cancer. The presented work contains recent studies on the impact of the breast tissue microbiome and metabolic alteration on the breast cancer microenvironment. Despite the increasing interest in the link between the microbiome and the metabolome in breast cancer, studies investigating the association with breast cancer are still very limited. The use of metabolomics, a sophisticated analytical approach, will precisely demonstrate the link between microbiome and metabolome in the microenvironment in breast cancer in order to aid in diagnosis, prediction, and treatment response. Notably, sample preparation in metabolomic studies using cells or tissues can highly impact the level, stability, and type of metabolites identified. Therefore, appropriate standardized protocols to estimate the metabolic changes in breast cancer cells or tissues remain essential. Future studies on a large-scale, including retrospective and prospective studies, are needed to provide new insights into the implications of the microbiome and metabolomics in the breast cancer microenvironment and how their complex interactions affect the tumor microenvironment's molecular networks and pathways. Additionally, in-depth studies investigating the role of 
the gut microbiome in breast cancer metabolism and its link to the breast cancer microbiome remain an urgent subject for further investigation.

Author Contributions: M.M.A.-A. and R.H.A. initially drafted the manuscript and L.A.D. reviewed the metabolomics section. A.M.A.R. has supervised the review. All authors have read and agreed to the published version of the manuscript.

Funding: This research received no external funding.

Acknowledgments: The authors would like to thank King Saud University and Department of Clinical Genomics and Center for genome medicine administrations at King Faisal Specialist Hospital and research center (KFSHRC). All the authors declare no conflict of interest associated with the study.

Conflicts of Interest: The authors declare no conflict of interest.

\section{References}

1. Alqahtani, W.S.; Almufareh, N.A.; Domiaty, D.M.; Albasher, G.; Alduwish, M.A.; Alkhalaf, H.; Almuzzaini, B.; AL-marshidy, S.S.; Alfraihi, R.; Elasbali, A.M. Epidemiology of cancer in Saudi Arabia thru 2010-2019: A systematic review with constrained meta-analysis. AIMS Public Health 2020, 7, 679. [PubMed]

2. Xuan, C.; Shamonki, J.M.; Chung, A.; DiNome, M.L.; Chung, M.; Sieling, P.A.; Lee, D.J. Microbial Dysbiosis Is Associated with Human Breast Cancer. PLoS ONE 2014, 9, e83744. [CrossRef] [PubMed]

3. Parida, S.; Sharma, D. Microbial Alterations and Risk Factors of Breast Cancer: Connections and Mechanistic Insights. Cells 2020, 9, 1091. [CrossRef] [PubMed]

4. $\quad$ Society, A.C. Cancer Facts \& Figures; American Cancer Society: Atlanta, CA, USA, 2016; pp. 1-72.

5. Yousef, A.J.A. Male Breast Cancer: Epidemiology and Risk Factors. Semin. Oncol. 2017, 44, 267-272. [CrossRef]

6. Lautrup, M.D.; Thorup, S.S.; Jensen, V.; Bokmand, S.; Haugaard, K.; Hoejris, I.; Jylling, A.-M.B.; Joernsgaard, H.; Lelkaitis, G.; Oldenburg, M.H. Male breast cancer: A nation-wide population-based comparison with female breast cancer. Acta Oncol. 2018, 57, 613-621. [CrossRef]

7. Ugnat, A.; Xie, L.; Morriss, J.; Semenciw, R.; Mao, Y. Survival of women with breast cancer in Ottawa, Canada: Variation with age, stage, histology, grade and treatment. Br. J. Cancer 2004, 90, 1138-1143. [CrossRef]

8. Sinn, H.P.; Kreipe, H. A Brief Overview of the WHO Classification of Breast Tumors, 4th Edition, Focusing on Issues and Updates from the 3rd Edition. Breast Care 2013, 8, 149-154. [CrossRef] [PubMed]

9. Tan, P.H.; Ellis, I.; Allison, K.; Brogi, E.; Fox, S.B.; Lakhani, S.; Lazar, A.J.; Morris, E.A.; Sahin, A.; Salgado, R. The 2019 World Health Organization classification of tumours of the breast. Histopathology 2020, 77, 181-185. [CrossRef] [PubMed]

10. Akslen, L.A.; Watnick, R.S. Biomarkers of the Tumor Microenvironment; Springer: Heidelberg, Germany, 2017 ; pp. 1-2.

11. Sazeides, C.; Le, A. Metabolic Relationship between Cancer-Associated Fibroblasts and Cancer Cells; Springer: Cham, Switzerland, 2018; pp. 149-165.

12. Lopes-Bastos, B.M.; Jiang, W.G.; Cai, J. Tumour-endothelial cell communications: Important and indispensable mediators of tumour angiogenesis. Anticancer Res. 2016, 36, 1119-1126. [PubMed]

13. Wang, B.; Xi, C.; Liu, M.; Sun, H.; Liu, S.; Song, L.; Kang, H. Breast fibroblasts in both cancer and normal tissues induce phenotypic transformation of breast cancer stem cells: A preliminary study. PeerJ 2018, 6, e4805. [CrossRef]

14. Aboussekhra, A. Role of cancer-associated fibroblasts in breast cancer development and prognosis. Int. J. Dev. Biol. 2011, 55, 841-849. [CrossRef]

15. Yamashita, M.; Ogawa, T.; Zhang, X.; Hanamura, N.; Kashikura, Y.; Takamura, M.; Yoneda, M.; Shiraishi, T. Role of stromal myofibroblasts in invasive breast cancer: Stromal expression of alpha-smooth muscle actin correlates with worse clinical outcome. Breast Cancer 2012, 19, 170-176. [CrossRef]

16. Wang, N.; Sun, T.; Xu, J. Tumor-related Microbiome in the Breast Microenvironment and Breast Cancer. J. Cancer 2021, 12, 4841-4848. [CrossRef] [PubMed]

17. Kovács, T.; Mikó, E.; Ujlaki, G.; Sári, Z.; Bai, P. Tumor Microenvironment; Springer: Heidelberg, Germany, 2020 ; pp. 137-153.

18. Wong-Rolle, A.; Wei, H.K.; Zhao, C.; Jin, C. Unexpected guests in the tumor microenvironment: Microbiome in cancer. Protein Cell 2021, 12, 426-435. [CrossRef] [PubMed]

19. Zheng, D.; Liwinski, T.; Elinav, E. Interaction between microbiota and immunity in health and disease. Cell Res. 2020, 30, 492-506. [CrossRef] [PubMed]

20. Urbaniak, C.; Kenderian, S.S. The microbiota of breast tissue and its association with breast cancer. Appl. Environ. Microbiol. 2016, 82, 5039-5048. [CrossRef]

21. Mani, S. Microbiota and Breast Cancer. Prog. Mol. Biol. Transl. Sci. 2017, 151, 217-229.

22. Nallu, A.; Sharma, S.; Ramezani, A.; Muralidharan, J.; Raj, D. Gut microbiome in chronic kidney disease: Challenges and opportunities. Trans. Res. 2017, 179, 24-37. [CrossRef] 
23. Kostic, A.D.; Xavier, R.J.; Gevers, D. The microbiome in inflammatory bowel disease: Current status and the future ahead. Gastroenterology 2014, 146, 1489-1499. [CrossRef] [PubMed]

24. Arnold, W.M.; Hill, E.S.; Fei, N.; Yee, A.L.; Garcia, M.S.; Cralle, L.E.; Gilbert, J.A. The Human Microbiome in Health and Disease. Genomic Applications in Pathology; Springer: Berlin/Heidelberg, Germany, 2019; pp. 607-618.

25. Gilbert, J.A.; Blaser, M.J.; Caporaso, J.G.; Jansson, J.K.; Lynch, S.V.; Knight, R. Current understanding of the human microbiome. Nat. Med. 2018, 24, 392-400. [CrossRef]

26. Pacifici, R. Distant Immune and Microbiome Regulation. Reference Module in Biomedical Sciences; Elsevier: Amsterdam, The Netherlands, 2019.

27. Yu, M.; Jia, H.; Zhou, C.; Yang, Y.; Zhao, Y.; Yang, M.; Zou, Z. Variations in gut microbiota and fecal metabolic phenotype associated with depression by $16 \mathrm{~S}$ rRNA gene sequencing and LC/MS-based metabolomics. J. Pharm. Biomed. Anal. 2017, 138, 231-239. [CrossRef] [PubMed]

28. Shaffer, M.; Armstrong, A.J.S.; Phelan, V.V.; Reisdorph, N.; Lozupone, C.A. Microbiome and metabolome data integration provides insight into health and disease. Trans. Res. 2017, 189, 51-64. [CrossRef]

29. Zhu, J.; Liao, M.; Yao, Z.; Liang, W.; Li, Q.; Liu, J.; Yang, H.; Ji, Y.; Wei, W.; Tan, A.; et al. Breast cancer in postmenopausal women is associated with an altered gut metagenome. Microbiome 2018, 6, 136. [CrossRef]

30. Chadha, J.; Nandi, D.; Atri, Y.; Nag, A. Significance of Human Microbiome in Breast Cancer: Tale of an invisible and an invincible. Semin. Cancer Biol. 2020, 70, 112-127. [CrossRef]

31. Eslami, S.Z.; Majidzadeh, A.K.; Halvaei, S.; Babapirali, F.; Esmaeili, R. Microbiome and Breast Cancer: New Role for an Ancient Population. Front. Oncol. 2020, 10, 120. [CrossRef]

32. Chen, J.; Douglass, J.; Prasath, V.; Neace, M.; Atrchian, S.; Manjili, M.H.; Shokouhi, S.; Habibi, M. The microbiome and breast cancer: A review. Breast Cancer Res Treat. 2019, 178, 493-496. [CrossRef]

33. Mikó, E.; Kovács, T.; Sebő, É.; Tóth, J.; Csonka, T.; Ujlaki, G.; Sipos, A.; Szabó, J.; Méhes, G.; Bai, P. Microbiome-Microbial Metabolome-Cancer Cell Interactions in Breast Cancer-Familiar, but Unexplored. Cells 2019, 8, 293. [CrossRef] [PubMed]

34. Wang, H.; Altemus, J.; Niazi, F.; Green, H.; Calhoun, B.C.; Sturgis, C.; Grobmyer, S.R.; Eng, C. Breast tissue, oral and urinary microbiomes in breast cancer. Oncotarget 2017, 8, 88122. [CrossRef]

35. Ahn, J.; Yang, L.; Paster, B.J.; Ganly, I.; Morris, L.; Pei, Z.; Hayes, R.B. Oral microbiome profiles: $16 \mathrm{~S}$ rRNA pyrosequencing and microarray assay comparison. PLoS ONE 2011, 6, e22788. [CrossRef] [PubMed]

36. Lasken, R.S.; McLean, J.S. Recent advances in genomic DNA sequencing of microbial species from single cells. Nat. Rev. Genet. 2014, 15, 577-584. [CrossRef]

37. Lee, Y.-J.; Nostrand, J.D.; Tu, Q.; Lu, Z.; Cheng, L.; Yuan, T.; Deng, Y.; Carter, M.Q.; He, Z.; Wu, L.; et al. The PathoChip, a functional gene array for assessing pathogenic properties of diverse microbial communities. ISME J. 2013, 7, 1974-1984. [CrossRef]

38. Brun, P. The profiles of dysbiotic microbial communities. AIMS Microbiol. 2019, 5, 87. [CrossRef]

39. Wang, Q.; Garrity, G.M.; Tiedje, J.M.; Cole, J.R. Naive Bayesian classifier for rapid assignment of rRNA sequences into the new bacterial taxonomy. Appl. Environ. Microbiol. 2007, 73, 5261-5267. [CrossRef]

40. Hiergeist, A.; Reischl, U.; Gessner, A. Multicenter quality assessment of $16 \mathrm{~S}$ ribosomal DNA-sequencing for microbiome analyses reveals high inter-center variability. Int. J. Med. Microbiol. 2016, 306, 334-342. [CrossRef] [PubMed]

41. Yang, Y.-W.; Chen, M.-K.; Yang, B.-Y.; Huang, X.-J.; Zhang, X.-R.; He, L.-Q. Use of 16S rRNA gene-targeted group-specific primers for real-time PCR analysis of predominant bacteria in mouse feces. Appl. Environ. Microbiol. 2015, 81, 6749-6756. [CrossRef]

42. Jovel, J.; Patterson, J.; Wang, W.; Hotte, N.; O’Keefe, S.; Mitchel, T.; Perry, T.; Kao, D.; Mason, A.L.; Madsen, K.L.; et al. Characterization of the gut microbiome using $16 \mathrm{~S}$ or shotgun metagenomics. Front. Microbiol. 2016, 7, 459. [CrossRef] [PubMed]

43. Xavier, J.B.; Young, V.B.; Skufca, J.; Ginty, F.; Testerman, T.; Pearson, A.T.; Macklin, P.; Mitchell, A.; Shmulevich, I.; Xie, L.; et al The Cancer Microbiome: Distinguishing Direct and Indirect Effects Requires a Systemic View. Trends Cancer 2020, 6, 192-204. [CrossRef]

44. Fernández, M.F.; Reina-Pérez, I.; Astorga, J.M.; Rodríguez-Carrillo, A.; Plaza-Díaz, J.; Fontana, L. Breast Cancer and Its Relationship with the Microbiota. Int. J. Environ. Res. Public Health 2018, 15, 1747. [CrossRef] [PubMed]

45. Costantini, L.; Magno, S.; Albanese, D.; Donati, C.; Molinari, R.; Filippone, A.; Masetti, R.; Merendino, N. Characterization of human breast tissue microbiota from core needle biopsies through the analysis of multi hypervariable 16S-rRNA gene regions. Sci. Rep. 2018, 8, 16893. [CrossRef] [PubMed]

46. Thompson, K.J.; Ingle, J.N.; Tang, X.; Chia, N.; Jeraldo, P.R.; Walther-Antonio, M.R.; Kandimalla, K.K.; Johnson, S.; Yao, J.Z.; Harrington, S.C.; et al. A comprehensive analysis of breast cancer microbiota and host gene expression. PLoS ONE 2017, 12, e0188873. [CrossRef]

47. Nejman, D.; Livyatan, I.; Fuks, G.; Gavert, N.; Zwang, Y.; Geller, L.T.; Rotter-Maskowitz, A.; Weiser, R.; Mallel, G.; Gigi, E.; et al. The human tumor microbiome is composed of tumor type-specific intracellular bacteria. Science. 2020, 368, 973-980. [CrossRef]

48. Urbaniak, C.; Cummins, J.; Brackstone, M.; Macklaim, J.M.; Gloor, G.B.; Baban, C.K.; Scott, L.; O’Hanlon, D.M.; Burton, J.P.; Francis, K.P.; et al. Microbiota of Human Breast Tissue. Appl. Environ. Microbiol. 2014, 80, 3007-3014. [CrossRef] [PubMed]

49. Banerjee, S.; Tian, T.; Wei, Z.; Shih, N.; Feldman, M.D.; Peck, K.N.; DeMichele, A.M.; Alwine, J.C.; Robertson, E.S. Distinct Microbial Signatures Associated with Different Breast Cancer Types. Front. Microbiol. 2018, 9, 951. [CrossRef] [PubMed]

50. Jacob, M.; Lopata, A.L.; Dasouki, M.; Abdel Rahman, A.M. Metabolomics toward Personalized Medicine. Mass Spectrom Rev. 2019, 38, 221-238. [CrossRef] 
51. Jacob, M.; Malkawi, A.; Albast, N.; Al Bougha, S.; Lopata, A.; Dasouki, M.; Rahman, A.A.A. A targeted metabolomics approach for clinical diagnosis of inborn errors of metabolism. Anal. Chim. Acta 2018, 1025, 141-153. [CrossRef]

52. Brauer, H.A.; Makowski, L.; Hoadley, K.A.; Casbas-Hernandez, P.; Lang, L.J.; Romàn-Pèrez, E.; D’Arcy, M.; Freemerman, A.J.; Perou, C.M.; Troester, M.A. Impact of tumor microenvironment and epithelial phenotypes on metabolism in breast cancer. Clin. Cancer Res. 2013, 19, 571-585. [CrossRef]

53. Gu, X.; Al Dubayee, M.; Alshahrani, A.; Masood, A.; Benabdelkamel, H.; Zahra, M.; Li, L.; Rahman, A.A.A.; Aljada, A. Distinctive Metabolomics Patterns Associated With Insulin Resistance and Type 2 Diabetes Mellitus. Front. Mol. Biosci. 2020, 7, 609806. [CrossRef]

54. Aleidi, S.M.; Dahabiyeh, L.A.; Gu, X.; Al Dubayee, M.; Alshahrani, A.; Benabdelkamel, H.; Mujammami, M.; Li, L.; Aljada, A.; Rahman, A.M.A. Obesity Connected Metabolic Changes in Type 2 Diabetic Patients Treated With Metformin. Front. Pharmacol. 2021, 11, 616157. [CrossRef]

55. Budczies, J.; Brockmöller, S.F.; Müller, B.M.; Barupal, D.K.; Richter-Ehrenstein, C.; Kleine-Tebbe, A.; Griffin, J.L.; Dietel, M.; Denkert, C.; Fiehn, O.; et al. Comparative metabolomics of estrogen receptor positive and estrogen receptor negative breast cancer: Alterations in glutamine and beta-alanine metabolism. J. Proteom. 2013, 94, 279-288. [CrossRef]

56. Cardoso, M.R.; Santos, J.C.; Ribeiro, M.L.; Talarico, M.C.R.; Viana, L.R.; Derchain, S.F.M. A Metabolomic Approach to Predict Breast Cancer Behavior and Chemotherapy Response. Int. J. Mol. Sci. 2018, 19, 617. [CrossRef] [PubMed]

57. Kaushik, A.K.; DeBerardinis, R.J. Applications of metabolomics to study cancer metabolism. Biochim. Biophys. Acta Rev. Cancer 2018, 1870, 2-14. [CrossRef]

58. Tan, J.; Le, A. Breast Cancer Metabolism. In The Heterogeneity of Cancer Metabolism; Le, A., Ed.; Springer International Publishing: Cham, Switzerland, 2018; pp. 83-93.

59. Günther, U.L. Metabolomics Biomarkers for Breast Cancer. Pathobiology 2015, 82, 153-165. [CrossRef]

60. More, T.H.; Roy, C.S.; Christie, J.; Taunk, K.; Mane, A.; Santra, M.K.; Chaudhury, K.; Rapole, S. Metabolomic alterations in invasive ductal carcinoma of breast: A comprehensive metabolomic study using tissue and serum samples. Oncotarget 2017, 9, 2678-2696. [CrossRef] [PubMed]

61. Tayyari, F.; Gowda, G.N.; Olopade, O.F.; Berg, R.; Yang, H.H.; Lee, M.; Ngwa, W.; Mittal, S.; Raftery, D.; Mohammed, S. Metabolic profiles of triple-negative and luminal A breast cancer subtypes in African-American identify key metabolic differences. Oncotarget 2018, 9, 11677. [CrossRef] [PubMed]

62. Budczies, J.; Denkert, C.; Müller, B.M.; Brockmöller, S.F.; Klauschen, F.; Györffy, B.; Dietel, M.; Richter-Ehrenstein, C.; Marten, U.; Salek, R.M.; et al. Remodeling of central metabolism in invasive breast cancer compared to normal breast tissue-A GC-TOFMS based metabolomics study. BMC Genom. 2012, 13, 1-11. [CrossRef]

63. Warburg, O. On the origin of cancer cells. Science 1956, 123, 309-314. [CrossRef] [PubMed]

64. Martinez-Outschoorn, U.E.; Balliet, R.; Lin, Z.; Whitaker-Menezes, D.; Birbe, R.C.; Bombonati, A.; Pavlides, S.; Lamb, R.; Sneddon, S.; Howell, A.; et al. BRCA1 mutations drive oxidative stress and glycolysis in the tumor microenvironment: Implications for breast cancer prevention with antioxidant therapies. Cell Cycle 2012, 11, 4402-4413. [CrossRef]

65. Valvona, C.J.; Fillmore, H.L.; Nunn, P.B.; Pilkington, G.J. The regulation and function of lactate dehydrogenase a: Therapeutic potential in brain tumor. Brain Pathol. 2016, 26, 3-17. [CrossRef] [PubMed]

66. Dennison, J.B.; Molina, J.R.; Mitra, S.; González-Angulo, A.M.; Balko, J.M.; Kuba, M.G.; Sanders, M.E.; Pinto, J.A.; Gómez, H.L.; Arteaga, C.L.; et al. Lactate dehydrogenase B: A metabolic marker of response to neoadjuvant chemotherapy in breast cancer. Clin. Cancer Res. 2013, 19, 3703-3713. [CrossRef] [PubMed]

67. McCleland, M.L.; Adler, A.S.; Shang, Y.; Hunsaker, T.; Truong, T.; Peterson, D.; Torres, E.; Li, L.; Haley, B.; Stephan, J.P.; et al. An integrated genomic screen identifies LDHB as an essential gene for triple-negative breast cancer. Cancer Res. 2012, 72, 5812-5823. [CrossRef]

68. Brown, N.J.; Higham, S.E.; Perunovic, B.; Arafa, M.; Balasubramanian, S.; Rehman, I. Lactate dehydrogenase-B is silenced by promoter methylation in a high frequency of human breast cancers. PLoS ONE 2013, 8, e57697. [CrossRef]

69. Rattigan, Y.I.; Patel, B.B.; Ackerstaff, E.; Sukenick, G.; Koutcher, J.A.; Glod, J.W.; Banerjee, D. Lactate is a mediator of metabolic cooperation between stromal carcinoma associated fibroblasts and glycolytic tumor cells in the tumor microenvironment. Exp. Cell Res. 2012, 318, 326-335. [CrossRef]

70. Lane, A.N.; Tan, J.; Wang, Y.; Yan, J.; Higashi, R.M.; Fan, T.W.-M. Probing the metabolic phenotype of breast cancer cells by multiple tracer stable isotope resolved metabolomics. Metab. Eng. 2017, 43, 125-136. [CrossRef]

71. Jain, M.; Nilsson, R.; Sharma, S.; Madhusudhan, N.; Kitami, T.; Souza, A.L.; Kafri, R.; Kirschner, M.W.; Clish, C.B.; Mootha, V.K. Metabolite profiling identifies a key role for glycine in rapid cancer cell proliferation. Science 2012, 336, 1040-1044. [CrossRef] [PubMed]

72. Xie, G.; Zhou, B.; Zhao, A.; Qiu, Y.; Zhao, X.; Garmire, L.; Shvetsov, Y.B.; Yu, H.; Yen, Y.; Jia, W. Lowered circulating aspartate is a metabolic feature of human breast cancer. Oncotarget 2015, 6, 33369. [CrossRef] [PubMed]

73. Torata, N.; Kubo, M.; Miura, D.; Ohuchida, K.; Mizuuchi, Y.; Fujimura, Y.; Hayakawa, E.; Kai, M.; Oda, Y.; Mizumoto, K.; et al. Visualizing energy charge in breast carcinoma tissues by MALDI mass-spectrometry imaging profiles of low-molecular-weight metabolites. Anticancer Res. 2018, 38, 4267-4272. [CrossRef]

74. Fernandez, L.P.; Cedron, M.G.; Molina, A.R. Alterations of Lipid Metabolism in Cancer: Implications in Prognosis and Treatment. Front. Oncol. 2020, 10, 577420. [CrossRef] 
75. Brockmöller, S.F.; Bucher, E.; Müller, B.M.; Budczies, J.; Hilvo, M.; Griffin, J.L.; Orešič, M.; Kallioniemi, O.; Iljin, K.; Loibl, S.; et al. Integration of Metabolomics and Expression of Glycerol-3-phosphate Acyltransferase (GPAM) in Breast Cancer-Link to Patient Survival, Hormone Receptor Status, and Metabolic Profiling. J. Proteome Res. 2012, 11, 850-860. [CrossRef]

76. Hilvo, M.; Denkert, C.; Lehtinen, L.; Müller, B.; Brockmöller, S.; Seppänen-Laakso, T.; Budczies, J.; Bucher, E.; Yetukuri, L.; Castillo, S.; et al. Novel theranostic opportunities offered by characterization of altered membrane lipid metabolism in breast cancer progression. Cancer Res. 2011, 71, 3236-3245. [CrossRef] [PubMed]

77. Mimmi, M.C.; Finato, N.; Pizzolato, G.; Beltrami, C.A.; Fogolari, F.; Corazza, A.; Esposito, G. Absolute quantification of cholinerelated biomarkers in breast cancer biopsies by liquid chromatography electrospray ionization mass spectrometry. Anal. Cell. Pathol. 2013, 36, 71-83. [CrossRef]

78. Bathen, T.F.; Geurts, B.; Sitter, B.; Fjøsne, H.E.; Lundgren, S.; Buydens, L.M.; Gribbestad, I.S.; Postma, G.; Giskeødegård, G.F. Feasibility of MR metabolomics for immediate analysis of resection margins during breast cancer surgery. PLoS ONE 2013, 8, e61578. [CrossRef]

79. Rossi, T.; Vergara, D.; Fanini, F.; Maffia, M.; Bravaccini, S.; Pirini, F. Microbiota-derived metabolites in tumor progression and metastasis. Int. J. Mol. Sci. 2020, 21, 5786. [CrossRef]

80. Wiebe, J.P.; Muzia, D.; Hu, J.; Szwajcer, D.; Hill, S.A.; Seachrist, J.L. The 4-pregnene and $5 \alpha$-pregnane progesterone metabolites formed in nontumorous and tumorous breast tissue have opposite effects on breast cell proliferation and adhesion. Cancer Res. 2000, 60, 936-943. [PubMed]

81. Flores, R.; Shi, J.; Fuhrman, B.; Xu, X.; Veenstra, T.D.; Gail, M.H.; Gajer, P.; Ravel, J.; Goedert, J.J. Fecal microbial determinants of fecal and systemic estrogens and estrogen metabolites: A cross-sectional study. J. Trans. Med. 2012, 10, 253. [CrossRef] [PubMed]

82. Sui, Y.; Wu, J.; Chen, J. The Role of Gut Microbial $\beta$-Glucuronidase in Estrogen Reactivation and Breast Cancer. Front. Cell Dev. Biol. 2021, 9, 631552. [CrossRef] [PubMed]

83. Ma, J.; Sun, L.; Liu, Y.; Ren, H.; Shen, Y.; Bi, F.; Zhnag, T.; Wang, X. Alter between gut bacteria and blood metabolites and the anti-tumor effects of Faecalibacterium prausnitzii in breast cancer. BMC Microbiol. 2020, 20, 1-19. [CrossRef] [PubMed]

84. Mikó, E.; Vida, A.; Kovács, T.; Ujlaki, G.; Trencsényi, G.; Márton, J.; Sári, Z.; Kovács, P.; Boratkó, A.; Hujber, Z.; et al. Lithocholic acid, a bacterial metabolite reduces breast cancer cell proliferation and aggressiveness. Biochim. Biophys. Acta Bioenergy 2018, 1859, 958-974. [CrossRef] [PubMed]

85. Sári, Z.; Mikó, E.; Kovács, T.; Jankó, L.; Csonka, T.; Lente, G.; Sebő, É.; Tóth, J.; Tóth, D.; Árkosy, P.; et al. Indolepropionic Acid, a Metabolite of the Microbiome, Has Cytostatic Properties in Breast Cancer by Activating AHR and PXR Receptors and Inducing Oxidative Stress. Cancers 2020, 12, 2411. [CrossRef] [PubMed]

86. Kovács, T.; Mikó, E.; Vida, A.; Sebő, É.; Toth, J.; Csonka, T.; Boratkó, A.; Ujlaki, G.; Lente, G.; Kovács, P.; et al. Cadaverine, a metabolite of the microbiome, reduces breast cancer aggressiveness through trace amino acid receptors. Sci. Rep. 2019, 9, 1300. [CrossRef] 